\title{
VOLTAIRE VE MICROMEGAS ADLI FELSEFİ HIKÂYYESİ ÜZERINE
}

\section{Hakan SOYDAŞ ${ }^{1}$}

\begin{abstract}
Öz: XVIII. yüzyıl ünlü Fransız düşünürü ve yazarı Voltaire, yaşamı boyunca deneyimlediği duygu ve düşüncelerini yazınsal alana da taşımıştır. Şiir ve tragedya yazarı ünlü düşünür, yaşadığ 1 kimi olaylar ve karşılaştı̆̆ 1 insanlarca etkilenmiştir. Kendine özgü üslubu ve felsefi yaklaşımıyla, yaşadığı devire ve topluma getirdiği eleştiri çağdaşlarını olduğu kadar kendinden sonraki düşünürleri de etkisi altına almıştır. Voltaire'in Micromégas adlı felsefi hikâyesi XVIII. yüzyıl Fransa'sındaki felsefe ve bilim çatışmasını konu edinmektedir. Yüzyılın bilim adamlarının, elde ettikleri bilimsel verileri kesin geçerli ilkeler olarak değerlendirmeleri ve tartışma kabul etmez yaklaşımları, düşünürün görelilik yaklaşımı çerçevesinde eleştirilmiştir. Katı bilimsel verilerin karşısına felsefi sorgulamaları koyan Voltaire, devrinin gerçekliğinin, gelecek yüzyılların yanılgısı olabileceğini işaret etmektedir. Gerek öyküleme biçemi gerekse de tercih edilen anlatı kişilerinin felsefi yaklaşımları ünlü düşünürün ortaya koyduğu tartışmanın yöntemini ve taraflarını belirlemesi açısından önemlidir. Yazar, kimi yazın eleştirmenlerince felsefi hikâyenin yaratıcısı olarak anılmakta ise de yazın tarihine dair yapılan artsüremli okuma, bu iddiayı doğrulamamaktadır. Voltaire'in sürgün yıllarında sığındığı İngiltere'de tanıştığı düşünürler ve yazınsal yapıtlar, yazarın imgelem dünyasını etkilemiştir. Jonathan Swift bu isimler arasında önceliğe sahiptir. Farklı akademik kaynaklarda görülen bulgular, ünlü İngiliz yazarın imgesel bir yolculuğu anlattığı yapıtını, M.S. II. yüzyılda Samsatlı Lukianos'un Gerçek Öykü adlı hikâyesinden etkilenerek kalem aldığını işaret etmektedir. Yapılan incelemeyle her üç yazınsal yapıtın izleksel ve biçemsel ortaklıkları tespit edilmeye ve Voltaire'in Micromégas adlı hikâyesindeki felsefe-bilim çatışması serimlenmeye çalışılacaktır.
\end{abstract}

Anahtar Sözcükler: Felsefi Hikâye, Voltaire, Jonathan Swift, Lukianos, Seyahat.

\section{Giriş}

Felsefi hikâye eğlenceli ve gülünç kurgular içeren bir anlatı türüdür. Okuyucuyu düşünmeye iten bu anlatılar, okuyucuya bir ders vermeyi amaçlar. Öğretici ve tartışmaya açık bu anlatı biçemi okuyucuyu, sunulan iletinin geçerliliğine ikna

\footnotetext{
1 Araş. Gör., Atatürk Üniversitesi, Edebiyat Fakültesi, Fransız Dili ve Edebiyatı Bölümü. hakan.soydas@atauni.edu.tr
} 
edebilmek için kurgu sanatını kullanır. Anlatı çevremi gerçek dünyaya göndergelerle doludur. Anlatı biçeminin tartışmacı yönü alegorik bir betimlemeyle açımlanır. Böylelikle yazar okuyucuya, sembolik anlamlar yüklenen anlatı kahramanlarının özel isimleriyle ${ }^{2}$ toplumsal değer yargılarına atıfta bulunur. Aynı zamanda da okuyucuya karakter analizinde kullanabileceği yapı taşları da sunar. Yazar okuyucuya sunduğu böylesi ipuçları ile okuyucuyu analitik bir çözümleme yapmaya yönlendirir. Anlat1 boyunca betimlenen olay örgüsü anlam belirsizliğine neden olmayacak düzeyde yazarın sorguladığı ve savunduğu etik değerlerin okuyucu tarafından alımlanmasını sağlar. Felsefi hikâyedeki bu anlam arayışı aynı zamanda okuyucuyu da kimi iç sorgulamalara sürükler. Anlatıdaki öğretici ileti apaçık sunulmaz ama ironi ile ima edilir ve dolaylı bir tartışma ortamı hazırlanır.

XVIII. yüzyıl yazarları, siyasi erk ve onun kurumlarını eleștirmek için sık s1k ahlaki hikâyeleri kullanmışlardır. Kurgu ilk aşamada karşılaşılabilecek sansür tehdidine karşı bir perde görevi görür. Metnin önceliği bir ileti sunmak değil, okuyucuyu düşünmeye itmektir. Verilen ders ahlaki, toplumsal ve felsefi olabileceği gibi siyasi de olabilir. Fransa'da felsefi hikâyelerin altın çağı XVIII. yüzyıldır. Aydınlanma filozofları Doğu hikâye geleneğinden esinlenerek; bu türü düşüncelerini yaymak için kullanmışlardır. Anonim bir yapıt olan Bin Bir Gece Masalları Voltaire'in kurgu dünyasını besleyen birincil kaynaklardandır (Voltaire, 2006, s. XVI). Dünyanın en iyi hikâye kitaplarından olan bu ünlü yapıt Avrupa'ya Fransiz bilim adamı Antoine Galland tarafindan XVIII. yüzyılın ilk on yılında Arapça aslından çevrilmek suretiyle Fransızcaya taşınır. İngilizceye yapılan ilk çeviri için Galland'ın Fransızca çevirisinden yararlanılmıştır. Arapça temel alınarak yapılan ilk çevri ise üç cilt halinde 18391841 yılları arasında Edward William Lane tarafindan yapılmıştır (Eliot, 1909, s. 3-4).

Felsefi hikâye (conte philosohique) yazınsal bir tür olmanın ötesinde yazınsal bir biçemdir. İngiliz Yazınında ise (philosophical fiction) felsefi kurgu olarak karşılık bulmaktadır. Voltaire felsefi hikâyenin babası addedilmesine rağmen, yapıtlarını tanımlamak için bu ismi hiçbir zaman kullanmamıştır (Delimat, 2011, s. 65). Voltaire'in mucidi olduğu kabul edilen felsefi hikâye, Batı kültür geleneğinde yer alan parabole anlatı biçeminin toplumsal ve felsefi sorgulamalar için kullanılmasıdır (Delimat, 2011, s. 64). Parabole anlatılar genellikle kısa, alegorik ve veciz bir söyleme sahiptir. Aynı zamanda kutsal metinlerdeki öğreti ve dersleri açıklayabilmek için kullanılmış bir anlatı türüdür. Okuyucu, okuma edimi boyunca anlatıda gizlenen alegorik anlam üzerine yoğunlaşır (Bourque, 1976, s. 161-187).

\footnotetext{
${ }^{2}$ Candide ou l'optimisme (Candide ya da İyimserlik, 1759), birinden bahsederken temiz yürekli, saf (bk. Littré E. (1889). Dictionnaire Littré.(Tome Quatrième). Paris: Edition Hachette.)
} 


\section{Voltaire ve İmgelem Dünyasının Kaynakları}

Hayalin çılgınlıklarına itimat etmeyen ve destan, betik, trajedi gibi büyük klasik türlerin yazınsal mükemmelliğine inanmış olan Voltaire, kırk beş yaşında ilk hikâyesini yazar (le Voyage du Baron de Gangan).1745-1760 yılları arasında yaşamış olduğu hayal kırıklıkları ve başarısızlıklar onu farklı bir yere yöneltmiştir. Felsefi hikâyenin doğduğu ve aşama aşama geliştiği bu süreç, böylesi yeni bir dönemdir. İdeal ve tecrübe arasındaki ayrılık daha sık dile getirilir. Voltaire'in mizacına uygun hikâyelerin daha fazla ortaya çıktığı bu dönemde, yazar belirli aralıklarla hayatın ona neler sunduğunu özetleme ihtiyacı hisseder. $\mathrm{Bu}$ nedenledir ki hikâyelerindeki kişiler onun kişiliğinin ve tepkilerinin yansımalarıdırlar. Anlatının kurgusu, felsefenin hayalden ve gülmekten ayrılamayacağına inanan bir adamın cevabı olur adeta. Anlatı kişileri sayesinde korku ve sıkıntıdan kurtulup, özgürleşen yazar, kendini geriye çekerken anlatı kişileri üzerinden ironiye başvurur; anlatı kişilerini maceradan maceraya sürükler. Kendilerine özgü bir iç dünyadan yoksun olan anlatı kişileri, Voltaire için, insanları eyleme yönlendirdiği ve onları metafizik sıkıntılardan koruduğu ayrıcalıklı vasıtalardır. John Locke ve onun duyumculuğunun taraftarı olan Voltaire, insan yazgısını, bireyin tecrübe yoluyla eğitimine öncülük eden iç dünyası ile bir bütünleşme dizisinin sonucu olarak görür. Kısacas1, Voltaire'in hikâyeleri bir bilinç ve dünya arasındaki kesişmeyi bağlayan öğretici anlatılardir (Charpenter, 1987, s. 128).

Voltaire XVIII. yüzyılın başında modern romanın biçemsel ve izleksel özelliklerinden uzak; doğulu egzotizmi ve aşırı serbest bir düşlemi işleyen yapıtlar kaleme alır. Onun için felsefe ve metafizik birbiriyle çatışmaktadır; çünkü metafizik insanın özü, ruhunun doğası ve Tanrıya izafe edilen nitelikler gibi kavranamaz, gözlemlenemez ve deneyimlenemez konularla ilgilenir (Parrau, 2013, s. 25). Voltaire'in metafiziğe ve tabii ki Kiliseye karşı katıksız duruşunun iz düşümleri onun hayatında görülebilir. François-Marie-Roulet, Voltaire, XIV. Louis Fransa'sında dünyaya gelmiştir. Noter olan babas1, mesleği gereği soylularla ve büyük burjuvalarla kişisel ilişkilere sahiptir. Voltaire'in çocukluğu böylesine bir çevrede geçmiştir. Babası Voltaire'in de ağabeyi gibi iyi bir Katolik eğitim alabilmesi için oğlunu Cizvitler yönetimindeki Louis-le-Grand Kolejine kaydettirir. Voltaire isteği dışında babasının zorlamasıyla kaydettirildiği bu okuldaki derslerinde başarılı olmakla birlikte Cizvit papazları ona dine karşı saygılı olmasını sağlamayı başaramamışlardır (Maurois, 2001, s. 110). Voltaire'in dine karşı olan çocukluk çağlarındaki bu tavrının nedenleri arasında, kendi rızası dışında bir eğitime tabi tutulması kadar, hiçbir zaman anlaşamadığı ağabeyinin mutaassıp bir kimliğe sahip olması da sayılabilir. Onun ilk eğitiminde çok önemli bir yere sahip olan bir başka isim ise rahip Châteauneuf 'dür. Châteauneuf alışıla gelmiş bir rahipten (père) farklı olarak kiliseden bağımsız bir din adamıdır (abbé). Epikurosçu hazcı yaşam felsefesini ve Montaigne'in kuşkuculuğunu Voltaire'e ilk tanıtan hocası Châteauneuf olmuştur (Tanilli, 2007, s. 16). 
Voltaire'in metafiziğe karşı olan katıksız duruşu siyasi erk kurumları için de geçerlidir. Babasının hukukçu olmasını istemesine rağmen, Voltaire kişisel ilişkilerini kullanarak bir elçinin yardımcısı olarak Hollanda'ya gitmiştir. Burada Régence idaresine karşı yazdığı eleştiriler nedeniyle de bir yıl boyunca Bastille hapishanesinde yatar. Bir yılın sonunda ise devrin âdetince sürgüne gönderilir. Bu bir yıllık süre boyunca yaptığı okumalar zihnini açmıştır. Özgür kalışının akabinde eski Yunan yazarı Sofokles'in, bilmeden annesiyle evlenen Kral Odipus'un "Oedipe" trajedisini sahneye koyar. Voltaire'in bu oyun sonrasında elde ettiği başarı sanatsal bir başarı olmanın ötesinde, dönemin politik ve sosyal durumunun bir sonucudur. Sonrasında ise Kral Naibine hücum eden isimsiz bir şiir Voltaire'e mal edilmiş ve yeniden Paris dışına sürgün edilmiştir.

Yazarın muhalif kimliği kendisine halk nazarında yoğun bir ilgi kazandırmıștır. Zamanla şiirleri ve trajedileriyle ilgi toplayan Voltaire aristokrasi ve yüksek burjuva tarafından tanınmış ve bu tanışıklık Voltaire'e yeni firsatlar sunmuştur. Artık yüksek cemiyetlere girmekte ve zekâsıyla insanları etkilemektedir. Bu durum Voltaire'in kendine olan güvenini de perçinlemiştir. Artık daha iddialı yargılarda bulunmakta ve çevresindeki insanlara karşı daha az müsamahakâr davranmaktadır. Soylu bir aileye mensup Chevalier de Rohan-Chabot, girdiği bir tartışma sonucunda Chabot'nun adamlarınca ağır bir şekilde dövülmüştür. $\mathrm{Bu}$ olayı içine sindiremeyen Voltaire gittiği her yerde bu soylu adam hakkında konuşmaya başlamış ve neticede de Bastille Hapishanesindeki birkaç günlük misafirliğinin akabinde ülke dişına sürgün edilmiştir (Maurois, 2001, s. 20-22).

Ünlü filozofun yaşadığı bu olaylar dizisi onun aristokrasiye, saraya ve kiliseye bakışını derinden etkilemiştir. Fransa onun için özgürlüklerin sınırlandı̆̆ı, fikirlerin hapsedildiği, düşüncenin ise sürgünlerle yıldırılmaya çalışıldığı bir ülkedir artık. Edindiği tecrübeler onu daha da hırslı yapmış ve hırçınlaştırmıştır.

1726 yılının Mayıs ayında İngiltere'de ki sürgün günleri başlar. İngiliz yazınının seçkin yapıtlarını okuyabilmek için kısa zamanda İngilizce öğrenir ve hatta Epik Şiir Üzerine Bir Deneme (Essay On Epic Poetry, 1727) adlı yapıtı kaleme alır. İngiliz yazın ve siyaset dünyasının hemen bütün tanınmış simalarıyla tanışır. "Rabelais'den alabildiğince üstün” dediği Jonathan Swift'le tanışması onda büyük bir etki bırakacak ve ondan yergi sanatını öğrenecektir (Tanilli, 2007, s. 29). Bu suralar Jonathan Swift'in Gulliver'in Seyahatleri (1726) adlı kitabı basılmış ve satışa çıkmıştır. Voltaire zaman kaybetmeden bu “eğlenceli, çok ilginç, hayal dolu, üslubu çok hafif” kitabı Fransızcaya çevirir (Maurois, 2001, s. 28). Kesin tarihi bilinmemekle birlikte Voltaire 1729 y1linda Fransa'ya geri döner. İngiltere'deki çalışmalarından ve maruz kaldığı etkileşimin sonucunda Felsefi Mektuplarl (Lettres Philosophiques, 1734) kaleme alır. Bu kitap aynı zamanda yazarın İngiltere izlenimleridir. Voltaire bu yapıtlarıyla yurttaşlarına İngiliz toplumunu ve aydın sınıfını tanıtmaya çalışacaktır. 
Yazar yaşadığı tecrübeler, okuduğu eserler ve birlikte olma firsatını elde ettiği düşünür ve yazarlarca da etkilenmiş, yazınsal eserlerinde bu etkilerin izlerinin sürülmesine imkân tanımıştır. Bolingbroke'un Bir Yurtsever Kral Düşüncesi (1738) adlı yapıtı onu aydın monarşisi düşüncesine ne denli yaklaştırmış ise, Milton'un Yitirilmiş Cenneti (1667) ve Rabelais'den daha üstün gördüğ̈̈ Swift'den öğrendiği eleştiri sanatı ise yazarın yazın hayatında o denli etkili olmuştur (Tanilli, 2007, s. 29). Yazarın sonraki yıllarda kaleme aldığı Micromégas adlı felsefi hikâyesi de Gulliver'in Seyahatleri ile aynı ölçüde kurgu ve gerçeklik arasında göndergelerle doludur. Ünlü Fransız düşünür, esin kaynağı Swift gibi imgesel bir yolculuk izleğini tercih etmiş, adeta insanın gerçeklik algısını ters yüz edercesine anlatı uzam ve kişilerini yaratmıştır.

\section{Voltaire'in Felsefi Yaklaşımı ve Micromégas}

Voltaire, kelimenin modern karşıllğı itibari ile sıradan bir filozof olmanın ötesindedir. Ünlü düşünür aynı zamanda yetkin bir yazın insanıdır. Şiirler kaleme alan ve tiyatro oyunları sahneye koyan düşünür, felsefi yaklaşımı ile de farklı düşünürler üzerinde etkisini hissettirir. Leibniz, Malebranche ve Descartes gibi kabul görmüş filozoflar için eleştirel yazılar kaleme alır. Bununla birlikte boş ve faydasız felsefi sorgulamanın panzehiri olarak doğa bilimi anlayışının sıkı bir savunucusudur. Bilim ve felsefe arasındaki bu ayrımı netleștirmede ve özellikle bağnazlık ve batıl inanca karşı yürütülen mücadelede Voltaire, modern felsefede takip edilen kimi yöntemleri öncelemiştir.

İngiltere'deki sürgün yılları Voltaire' de derin izler bırakmıştır. Fransa'yı bir şair olarak terk eden Voltaire, ülkesine bir bilgin olarak geri dönmüştür. Sürgün yıllarında kaleme aldığı Felsefi Mektuplar İngiltere'de yaşadığı düşünsel dönüşümün izlerini taşır. Saray tarafından mahkûm edilen ve yasaklanan yapıt, Batı felsefe tarihi için önemli bir aşamadır. İlk olarak Newtoncu bilimsel yaklaşım bu dönüşümün aracı olmuştur. XVIII. yüzyılın ilk yarısı özellikle Fransa'da Newtoncu bilimsel yaklaşımın yapısı ve geçerliliği üzerine bir dizi tartışmaya şahit olmuştur. Voltaire'in yazınsal yapıtlarında, maruz kaldığı bu etkiyi görebilmek pekâlâ mümkündür. Ünlü düşünürünün düşünce yapısını etkileyen İngiliz felsefecilerinin önde gelenleri Johne Locke ve Newton olmuştur. Yazar, Tanrı'ya dinle dogmanın dışında bakan İngiliz düşünürleri Newton ve Locke'u tanıdıktan sonra (Tanilli, 2007, s. 34) kaleme aldığ Felsefi Mektuplar' ', Newton ve Descartes arasında bir itiraz için kullanmış, böylelikle İngiliz ve Fransız felsefesi arasındaki temel farklılıkları ortaya koymuştur. Voltaire yapitında, Fransiz filozof Descartes ve Malebranche'in hatalarına karşın Bacon, Locke ve Newton ile doğruyu aramaktadır. Voltaire'in alevlendirdiği bu tartışma daha sonra Kraliyet Bilimler Akademisine mensup küçük bir genç grup tarafından devralınmış, Voltaire ve Du Châtelet "Fransız Akademik Kartezyenizm"ine karşı Newtoncu bilimsel yaklaşımın lehine yürüttükleri çalışmalar ile yönlendirmişlerdir. Yürütülen bu çalışmanın merkezinde Voltaire'in Newton Felsefesinin Unsurlar (1738) adl1 yapitı bulunmaktadır (Shank, J. B, 2010). 
Anlaşılmaktadır ki Voltaire, sürgün yıllarında gerek tanıştığı çevre gerekse de okuduğu yeni kaynaklarla birlikte kendine özgü felsefi bir yaklaşım belirlemiş, kendi ülkesinin geçerli bilimsel ve felsefi kabullerindense misafiri olduğu İngiltere'nin entelektüel yapısını benimsemiştir. $\mathrm{Bu}$ tercihinde ülkesinde muhatap olduğu yasaklamaların ve mahkûmiyetlerin belirleyici olduğu düşünülebilir. Daha özgür davranabildiği ve kendini ifade edebildiği İngiltere'nin fikri alt yapısı ünlü düşünürü sımsıkı sarmalamıştır. XVII. yüzyılın ünlü Fransız düşünürlerini ötelemiş olması ve İngiliz düşünürleri kendisi için referans alması bunun bir sonucu olarak görülebilir.

Voltaire Micromégas adlı hikâyesini, inzivaya çekildiği Emile de Chatelet'nin ev sahipliğinde; bilimsel düşüncelerinden hareketle kaleme almıştır. Micromégas'da "relativité", "görelilik", kuramına göndermede bulunmaktadır. Voltaire bu felsefi yaklaşımı etik anlamda ele almıştır. Şayet insan evrende fark edilemeyecek bir noktadan ibaretse; her şeyin merkezinde insanın olduğu ve her şeyin ardındaki gizemi yalnızca insanın kendisinin bilebileceği bahanesiyle onun, diğer hemcinslerine zulmetme kibri neye dayamaktadır. Metafizik ve hoşgörüsüzlük birbirine bağlı iki olgudur. İnsanın özgürlüğü metafiziğin sebep olduğu ön yargıları kırmakla mümkündür. Ünlü filozof kendini bu mücadeleye adamıştır.

Micromégas'nın orijinal baskısı 1752 Mart ayında yayımlanmıştır. Berlin'de 1750 tarihli bir bask1s1 olmakla birlikte, 1752 Mart ayından önce bu hikâyeye dair hiçbir iz bulunmamaktadır. $\mathrm{Bu}$ sebeple ilgili baskının yanlış tarihlendirildiği düşünülmektedir.

Voltaire'in 1752 Haziran ayında Bibliothèque Impartiale editörüne gönderdiği mektupta, eserlerini "eğlendirici kadim hikâye" olarak nitelemesi bu iddiay1 desteklemektedir. Bununla birlikte 1739 Haziran ayında Voltaire, Prusya Kralı II. Fredéric'e La relation de voyage... de M. Le baron de Gangan adlı hikayeyi gönderir. Kralın 7 Temmuzda yazdığı cevapta anlatı kahramanı Gangan için "voyageur céleste" (olağan üstü gezgin) der. Burada "céleste" sıfatının olağanüstü, sıra dışı anlamlarının yanı sıra göğe değin, gökle ilgili anlamları da değerlendirilecek olunursa; söz konusu hikâyenin, Sirius yıldızından Micromégas ve Satürn gezegeni Akademi Sekreteri, anlatı kişileri ile arasındaki anlamsal ilişki rahatlıkla kurulabilecektir. Mektubun devamındaki, "bu olağan üstü gezgin insanların büyük diye nitelendirmeye alışageldikleri ölçüyü (göreceliği) değiştirmektedir" ifadesi ise Micromégas'nın bugün kayıp olan Le voyage de Gangan (Ganganın seyahati) adlı küçük denemenin yeniden ele alınıp farklı konularla yenilenmiş son hali olduğu yargısına varılabilir (Voltaire, 1960, s. I-XII). Bir başka dikkat, Micromégas'nın, Jonathan Swift'in Gulliver's Travels (Gulliver'in Seyahatleri) (1726) adlı yapıtından etkilenerek kaleme alındığı iddiasıdır. Voltaire, Micromégas adlı yapıtında gerçek ve kurgu

\footnotetext{
${ }^{3}$ Voltaire'in öncelediği ve hikâyesinde işlediği görelilik kuramının sonraki yüzyıllarda yaşadığı evrim ve etki alanları hakkında daha geniş bilgi için, bk. ZEKIYAN, B. (1982). İnsancılık. İstanbul: İnkılâp ve Aka Kitabevleri, s. 1-14.
} 
arasında canlı bir ilişki kurmaya çalışır. Bu ilişki çerçevesinde sunulan hikâye, Voltaire'in düşüncelerini iletmek için kullanılır. Yazar, sunulan diyaloglar ve betimlemeler ile hikâyede kendini okuyucuya hissettirir. Hikâyenin başkahramanı ile kendini özdeșleștirmiştir. Anlatı kișisi Micromégas da Voltaire gibi Cizvit kolejinden mezun olmuştur. Micromégas'nın gezegeninden kovulmasına neden olan bilimsel kitabı gibi Voltaire de kendisine atfedilen bir eleştiri yazısı yüzünden ülkesinden sürgün edilmiştir. Hikâyede kullanılan komik ve alegori unsurları ise yazarın yapıtını kaleme aldığı XVIII. yüzyıl Fransa's1 için özel bir durumdur. Nasıl ki XVII. yüzyılın ünlü düşünürü Descartes' in latince yazdığı ilk felsefi yapıtı Méditations Métaphysiques (Metafizik Düşünceler, 1641) devrin otoritelerince din dışı görülerek yasaklamış ve yakılmış ise, Voltaire de ünlü düşünürle aynı kaderi yaşamamak için karşı çıktığı düşünceleri ve karşılarına çıkardığı yeni düşünceleri komik ve alegorik unsurlarla ele almıştır. Hikâyedeki komik unsurlar yalnızca okuyucuyu güldürmek için değil, aynı zamanda düşünmeye itmek için kullanılmışlardır. Karş1 çıkılan düşünceleri küçümsemek için kullanılan komik unsurlar, bu savların kabul edilemezliğini işaret etmek için alegorik bir biçemle ele alınmışlardır. Bu sayede hikâye boyunca, okuyucu ve anlatıcı arasında canlı bir bağ kurulmakta ve okuyucu sürekli düşünmeye ve tartışmaya itilmektedir.

\section{Jonathan Swift ve Gulliver'in Seyahatleri'nin Micromégas'da İz Düşümleri}

İngiliz yazar Jonathan Swift'in XVIII. yüzyıl Fransız toplumuna büyük etkisi olmuştur. Yazarın Conduct of Allies (1711) adlı yapıtı aslı ile aynı zamanda Fransa'da, La Haye'de, görülür. Bununla birlikte Jonathan Swift ancak 1720 yılına doğru Tale of a Tub (1704) adlı yapıtının iki farklı Fransızca çevirisi ile Fransız toplumunun ilgisini çekmeyi başarmıştır. Swift'in asıl başarısı ise Gulliver's Travels (Gulliver'in Seyahatleri, 1726) ile gelir ve yazarm ismi, Fransız dergilerinde eskiye göre üç kat daha fazla görülür. Gulliver'in Fransa'daki etkisi fark edilebilir düzeydedir. Swift'in ilgili yapıtı alegorik, felsefi ve hayali yolculuklar yığınının doğmasına neden olmuştur. Bunların içinde birinci sırada Voltaire'in Micromégas adlı hikâyesini saymak gerekir (Paul, 1925, s. 489-490). Prof. İrfan Şahinbaş'a göre de "Voltaire'in Micromégas'sı Gulliver'in devler ülkesine seyahatini taklit eder. (...) Bu masal daha ziyade felsefidir ve felsefe nazariyle alaylıdır" (Swift, 1958, s. VIII).

Swift'in yapıtlanı, özellikle de Gulliver'in Seyahatleri, hayatı ile yakından alakalıdır. Swift'in yaşamındaki dönüm noktalarını tespit etmek aynı zamanda yapıtlarının temel yapı taşlarının keşfedilmesini sağlayacaktır. Yazar, $30 \mathrm{Kasım}$ 1667 yılında İrlanda'nın Dublin şehrinde doğmuştur. Swift, "İrlanda da doğmuş olmam benim için büyük bir felaket olmuştur; bu, bana kaderin oynadığı kötü bir oyundur" der. İngilizler için İrlanda medeni değildir ve medeni bir ülke tarafından yönetilmeye muhtaçtır. Bu nedenle, İngiltere ve İrlanda'nın ilişkileri eşit temellere dayanmamaktadır. Swift hak ettiği başarıya ulaşamamasının ve yaşamı boyunca başarısızlıklarla yüzleşmesinin nedenini İrlanda'da doğmuş olmasına bağlar. Çok parlak olmayan bir üniversite eğitiminin sonunda, hamisi 
olan amcasının ölümünün ardından yirmi yaşında İngiltere'ye gider. Seçkin bir siyasetçi Sir William Temple'ın özel kâtibi olur ve uzunca bir "uşaklık" deneyiminden sonra hayata atılmak ve sorumluluk üstlenmek üzere, efendisinin yardımıyla İrlanda'da bir köy kilisesine atanır. Yaşadığı hayal kırıklıkları Swift'in yeniden efendisinin hizmetine dönmesine neden olur. Bu yıllar yazarın, tarih ve klasik yapıtlarla meşgul olduğu yıllardır. İngiltere'de bir kiliseye tayin edilmesi için çokça girişimlerde bulunsa da bu isteğinde başarılı olamaz. İrlanda baş hâkimlerinden birinin kâtibi olacakken başarısız olmasını; büyük bir kiliseye dean (piskoposluktan bir aşağı rütbe) olmasının hayal kırıklığını, İrlanda kökenli olmasına bağlar. Swift, tüm bunlar üzerine ülkesi İrlanda'ya geri döner. İrlanda'daki kilise rahipliğinden, Londra'daki siyasi tecrübelerine değin yaşadığ talihsizlikler onu kendi ülkesinde İngiltere'ye karşı sert muhalefet yazıları yazan bir yazarlığa taşır. Bu tavrı nedeniyle ülkesinde bir halk kahramanı ilan edilir. 1726 yılında yayınladığ Gulliver'in Seyahatleri yazarına dünya çapında bir şöhret kazandırır (Swift, 1958, s. I-VI).

Yapıt, insanın dört farklı yönünü ele alan bir eleştiridir. Ele alınan izlekler insanın fiziki, politik, zihinsel ve ahlaki yönleridir. Gulliver'in Seyahatleri, dört bölümden oluşmaktadır. Birinci kitapta, başta Fransa ve Britanya olmak üzere modern politik uygulamalar; ikinci kitapta, Roma veya Sparta modelinin bir şey hakkında geçmiş politik uygulamaları; üçüncü kitapta, modern felsefenin politik uygulamaya etkisi; dördüncü kitapta geçmiş ütopya politikaları, insanı anlamayı dileyen insanı yargılamak için kullanılan bir ölçüttür (Barut, 1999, s. 141-142).

Voltaire, babasının mesleği gereği toplumun yüksek mevkiindeki insanlarla iç içe bir hayat yaşar. Yüksek tabakaya ne denli yakın olsa da, bu sosyal tabakayla arasında hissedilir bir sınır vardır. Voltaire'in babasının, oğlunu bir avukatın yanına sokmak istemesi de oğlunun geleceği için duyduğu endişenin sonucudur. Voltaire ise babasının bu zorlamasına karşılık kendi yolunu tercih etmiştir. Hollanda için gönüllü yolculuğunu sonraki yıllarda sürgün günleri izler. Voltaire'in talihi kimi zaman yönetici seçkin sınıfla zaman zaman barışması söz konusu olsa da, hayatı boyunca bu toplumsal sınıfla yadsınamaz çatışmalar tecrübe etmiştir. Jonathan Swift'in hayatının özetlendiği önceki paragraflarda betimlenen hayal kırıklıkları ise kendisine vaatlerde bulunan yönetici seçkin sınıfa karşı duyduğu öfkenin temel nedenlerindendir. Yazar İngiltere'ye karşı duyumsadığı aidiyet duygusunun karşılık bulmaması sonucunda İrlanda'ya nihai dönüşünde, İngiltere için amansız bir düşmanlık besler. Gerek Voltaire sürgün yıllarında yaşadığı İngiltere'ye duyduğu hayranlığa karşın Fransız toplumuna karşı beslediği öfke ile Jonathan Swift'in İrlanda kökenli bir İngiliz olarak uğradığı talihsizlikler her iki yazarın, yaşadığı aidiyet sorununu işaret etmektedir.

Voltaire ve Jonathan Swift, yaşadıkları çağ ve toplum için karşıt iki yazardırlar. Voltaire babasının zorlamasıyla Cizvit kolejine gider ama Cizvit tarikatının ona sunduğu anlam dünyasını hiçbir zaman özümseyemez. Jonathan Swift Angloİlandalı bir eleștirmendir (Lersen, 2005, s. 19). Bu terim öncelikle XIX. yüzyılda ve XX. yüzyılın ilk yıllarında İrlanda'da ayrıcalıklı bir sınıfı 
tanımlamak için kullanılır. Bu topluluğun üyeleri Protestan Ascendancy'nin varisleridir ve İrlanda kilisesine mensupturlar. Swift'in annesi İngilterenin, Frisby on the Wreake, babası ise Goodrich köyü kökenlidir. Anlaşılacağı üzere, Jonathan Swift, henüz daha doğmadan ailesi anavatanından kopar ve Swift de köklerinden kopmuş bir yetim olarak dünyaya gelir. Jonathan Swift etnik kökleri ve aldığı eğitim gereği bir Protestan'dır. Gözlerini dünyaya açtığ1 İrlanda ise Katolik bir ülkedir. Swift'in ailesi İrlanda'yı Protestanlaştırma amacı güden İngiltere'nin iskân politikası nedeniyle İrlanda'ya yerleştirilmiştir. Swift, dünyaya geldiği ilk günden beri hem dinsel hem de etnik bir uyuşmazlığın ortasında bulmuştur kendini. İngiltere'deki başarısızlıklarının nedeni olarak İrlanda da doğmuş olmasını göstermesi, yaşadığı duygu karmaşasını açıklamaktadır. Voltaire ve Jonathan Swift din konusunda olağan dış1 tecrübelere sahiptirler. Voltaire Katolik bir ülkede ve Katolik tarikatına ait Cizvit tarikatında eğitim görmüş ama yaşamının ilerleyen yıllarında kendini bir deist olarak tanımlamıştır. Jonathan Swift ise bir Protestan olarak Katolik bir ülkede doğmuş; ana vatanında yaşadığı olumsuz tecrübeler sonucunda geri döndüğü Katolik İrlanda'da Protestan bir din adamı olarak yaşamını sürdürmüştür. Ne yazık ki, Swift ve Voltaire arasındaki kişisel ilişkiler hakkında yeterli bilgiye sahip değiliz. Diğer taraftan muhtemeldir ki Voltaire 1727 y1lında İngiltere'deki son ikametinde Swift ile s1k s1k görüşmüştür (Paul, 1925, s. 489490).

Hayatlarındaki iz düşümleri kadar, her iki yazarın ele alınan yapıtlarının biçemsel paydaşlıkları önemlidir. Swift' in Gulliver'in Seyahatleri adlı yapıtının, Voltaire'in Micromégas'sında merkeze oturtulan ve geliştirilen görelilik düşüncesini ele alıp işlediği gözden kaçırılmamalıdır (Tanilli, 2007, s. 68). İngiliz düşünür Johne Locke ve Isaac Newton'dan etkilenen Voltaire, düşünce hayatında İngiliz düşünürleri öncelediği gibi yazınsal alanda da İngiliz yazar Swift'den etkilenmiştir. Felsefi bir arka planın yolculuk izleği ile seyrine tanık olduğumuz yapıtlar kurgu dünyasının araçları ile gerçek dünyanın değer yargılarını ve ölçülerini alaycı bir biçemde işlemektedir. Voltaire, imgesel yolculuk izleğini Swift'e borçludur. Gerçekliğin sorgulanabilir hale gelmesi ve toplumsal değer yargılarının sorgulanabilir kılınması her iki yapıtta da görülmektedir. Anlatı kişilerinin aynı zamanda birer toplumsal sınıfı temsil eden tipler olarak kullanılması ve felsefi sorgulamaların bu tipolojiler üzerinden yürütülmesi okuyucuyu anlatının anlam dünyasına çekmektedir.

\section{Gulliver'in Seyahatleri ve Gerçek Hikâye}

Gulliver'in Seyahatleri Swift'e özgü bir biçem değildir. Lukianos, Gerçek Hikâye (Verae Historiae) adlı yapitıyla bu biçemin ilk örneklerinden birini vermiştir. Lukianos başka benzer hikâyeler de yazmıştır. Bu hikâyede, kimi inançlar, kurumlar, filozoflar eleştirilmekte ve hayal ürünü hikâyelerle alaya alınmaktadır (Swift, 1958, s. VII).

Swift'in Lukianos'u okuduğuna dair bir bilgiye sahip olmamakla birlikte Journal to Stella'ya (Journal to Stella, Letter XIII, January 4, 1710-1711) 
yazdığı: "Bateman kitapçısına gittim... ve Stella içi Lukianos'un Fransızca üç küçük cildini satın aldım" ifadesi Swift'in Lukianos'tan ve yazınsal yapıtlarından haberdar olduğunu göstermektedir. Ortak yönleri de düşünüldüğünde Gerçek Hikâye'nin Gulliver'in Seyahatleri'nin çok belirgin bir kaynağı olduğu anlaşılmaktadır (Eddy, 1921, s. 419-422).

Hayali yolculuk ve eleştirel, alegorik, ütopyacı farklı biçimleri içeren tür, geniş kapsamlı çalışmalara konu olmuştur. Lukianos' un Gerçek Hikâye' si Jonathan Swift'in Gulliver'in Seyahatleri başta olmak üzere farklı yazarlar ve yapitlar üzerinde de önemli etkileri olmuştur (Larmour, 1998, s. 44-45). İşaret edilen bu etki, "Kıta Avrupası Felsefesi" nin kaynaklarının doğal bir sonucudur. Bu düşünce geleneği tarihin farklı dönemlerinde kesintilere uğramıştır. Rönesans ve Aydınlanma Çağı gibi, yaşanılan devrin ve değer dizgelerinin sorgulamaya açıldıkları düşünsel dönüm noktaları, Batılı düşünürleri Greko-romen kültüre yöneltmiştir. Bu yöneliş sıradanlıktan ve bayağılıktan uzak, varlığın ve bilginin nedenselliğine yönelik farklı ve özgün yaklaşımlara kapı aralamıştır. Felsefi hikâye biçemi ise, Yunan kültür dairesine girmiş doğulu bir bilgenin gerçek ve hakikat karşısında aldığı tavrın ürünüdür. Platon'un "mağara alegori” sinden beri gerçeklik ve yanılsama ontolojik düzlemde ele alınmıştır. Bu düşünce geleneği aynı zamanda birbirinden farklı eleştirel bakış açılarını beslemiştir.

Eleştiri alanındaki yaygın kanaate göre ise Lukianos modern eleştirmenlerin ilkiydi. Romalı düşünür Petronius gibi o da, şairlerin birçok basit soyutlamalarından daha çok günlük hayatın, farklı yönleri ve bayağılığı ile yazına zengin bir malzeme sunmakta olduğunu keşfetmiştir. Doğacılardan daha az bilgiççe ve daha etkili bir gözlemle geleneğin yerini almıştır. Dünyayı, gerçeğin ışığında gösterir. İnsanoğlunun çağlardır süregelen kibri yüzünden Lukianos' un yazılarında nadiren ilkçağın soluk bakış açısı görülür. Kahramanları II. yüzyılda olduğu gibi bugünün insanına da benzer. Yazın tarihinde ilk defa bütünüyle dünyayı konu edinen bir yazarla karşılaşıyoruz. Diğer birçok isim kendini şair, tarihçi ya da filozof olarak tanıtırken Lukianos ise yazınla ilgilenmiştir (Whibley, 1902).

Voltaire, Jonathan Swift ve Lukianos üzerine yapılan art süremli okuma, her üç yazarın da hayatlarında birbirlerine yakın başarısızlıklara ve hayal kırıklıklarına maruz kaldıklarını göstermektedir. Lukianos'un II. yüzyılda dünyaya ve çağının bilginlerine yönelttiği bakış açısı Swift ve Voltaire'in XVIII. yüzyıldaki bakış açılarına yakın düşer. Önce sofist sonra ahlakçı olan filozofun çağının bilginlerine güvensizliği, bir sonraki bölümde çözümlenecek olan Micromégas aracılığıyla, Voltaire'in bilim adamlarına kuşkucu yaklaşımı birbirini tamamlar düzeydedir. Hayali ve olağan dışı bir yolculuk üzerine kurulan bahse konu üç yapıt da, adeta dünyadaki gerçeklik algımızı ve değer yargılarımızı sınamaktadır. Gerçeğin parodiyle buluştuğu yapıtlar, okuyucularını sıkıcı bir felsefi okuma ediminden alıkoymaktadır. Bununla birlikte, eğlendirici unsurlarıyla okuyucuyu kendi kurgu dünyalarına çekmekte; okuru düşünmeye ve tartışmaya yönlendirmektedir. 


\section{Felsefe-Bilim Çatışması}

Voltaire'in felsefi düşüncesi, hikâyelerin ilk serisinin yayımlandığı süre boyunca bir dönüşüme uğrar. XVIII. yüzyıl Fransız felsefi düşüncesi açısından "iyimserlik" ağır basar. İngiliz şair Alexandre Pope bu felsefi iyimserliğin ilk temsilcisidir. Leibniz ise ünlü şairin önüne geçmekle kalmaz aynı zamanda onu da aşar. Onun felsefi yaklaşımını daha da netleştirmek ve dizgeleştirmek isteyen Wolff ise ne yazık ki bu felsefi yaklaşımın zayıflamasına neden olur. $\mathrm{Bu}$ nedenle "felsefi iyimserliğin" kurucusu olarak Leibnitz kabul edilir. Leibnitz'in felsefesi iki temel iddia içermektedir: Tanrı iyidir ve Tanrının dünyamızı seçmiş olması dünyamızın diğer dünyaların en iyisi olmasıdır. Leibnitz'in dünya üzerinde kötülüğün varlığını kabul etmesine ve her şeyin iyi olduğunu iddia etmemesine rağmen, "iyimserlik teorisi" her şeyin yolunda olduğunu ileri sürmektedir. Yaşadığımız hayattaki bütün kötü olayların ise bu felsefi yaklaşımı yalanlıyor olmasi; Voltaire'in bu teorideki bariz çelişmeye tepki koymasına neden olur. 1748 yılında yayımladığı ilk önemli hikâye olan Zadig, ölçüsüz bir iyimserliğin ele alındığı felsefi bir hikâyedir. 1752 yılında yayımladığı Micromégas adlı felsefi hikayesi ise anlatı kahramanlarının Voltaire için adeta bir "kamuflaj" olarak kullanıldığı bir hikâyedir. Anlatı kahramanları anlatıcının gölgesinde kalırlar. Anlatı boyunca etken değil edilgen bir kimlikle hareket eder ve olayları öngöremezler. Anlatı kişilerinin bu "rolü" hikâyenin yazarı Voltaire'e, anlatıcı üzerinden yaşadığı çağa ve topluma eleştiri getirebilme imkânı sunar (Nahon, 1972, s. 9-14).

Anlatının öykülenmesinde "birinci tekil kişis" tercih edilirken; birinci tekil kişi bakış açısı ile birlikte gözlemci figürün bakış açısı kullanılmıştır. "Kimseyi yalancı çıkarmak istemem" (s. 44) sözcesi ile anlatıcının, tarafsızlık iddiası ile anlatıya yalnızca bir gözlemci olarak eşlik ettiği görülür. Anlatıcının okuyucuya olay örgüsünü sunarken aynı zamanda salt gerçekliği sunmaya çalıştığı iddia edilebilir. "Bir tarihçi için kolay bir iş olmasa da, olup bitenleri kendimden hiçbir şey katmadan anlatacağım" (s. 55) sözcesi ise, bu önermeyi doğrulamaktadır. Bununla birlikte bir tarihçi göndergesinin, anlatıcı üzerinden hikâyenin yazarına da göndermede bulunduğu düşünülebilir. Voltaire, İngiltere'de geçirdiği yıllarda yalnızca felsefi yazılar ile meşgul olmamış; dikkatini aynı zamanda tarih üzerine de çevirmiştir. Çağdaş tarihin konusu olan İsveç kralı XII. Charles'ın bir savaşta öldürülmesini kaleme aldığı çalışma, bu açıdan önemlidir. Takip ettiği çalışma yöntemi modern ve etkili sonuçları bakımından sağlam temellere dayanır. 1751 yılında yayımladığı XIV. Louis'nin Devri ve 1756 yılında yayımladığı Milletlerin Ruhu ve Muaşeretleri Üzerine Bir Eser adlı yapıtları Voltaire'in XVIII. yüzyılın İngiliz tarihçileri Hume Robertson ve Gibbon tarafindan üstat olarak kabul edilmesine neden olmuştur. Fransa'da olduğu gibi, İngiltere ve Amerika'da da Voltaire'in tarih konulu çalışmaları onun meşhur yazıları arasında en çok okunanlarıdır (Havens, 1971, s. 173-184).

Hikâye, iki anlatı kahramanı ve onların çevresinde yer alan diğer anlatı kahramanlarının etrafında şekillenmektedir. Anlatının başkahramanı Siriuslu 
Micromégas ve Satürn Akademi Sekreteridir. Anlatı kahramanlarının tespit edilmesi önemlidir; çünkü anlatı kişileri yazarın hikâyedeki sözcüleridirler. Onun kişiliğini ve tepkilerini yansıtırlar. Micromégas yazarın bilimlere karşı olan tutkusunu betimler (Charpenter-Charpenter, 1987, s. 128). Micromégas, Yunanca kökenli micro (küçük) ve méga (büyük) kelimelerinden oluşmaktadır. Küçük-büyük olarak karşıllı verilebilecek bu isim Voltaire'in ustaca bir eğretilemesidir. Anlamı güçlendirmek için iki zıt anlamlı kelimenin kullanılmış olması ve yazarın oksimoron söz sanatını tercih etmiş olması, okuyucuyu anlatının en başında düşünmeye ve tartışmaya itmektedir. Micromégas insanoğlunun değer biçmek için; bir şeyin değerini düşürmek ve yükseltmek ihtiyacına vurguda bulunmaktadır (Wade, 1950, s. 102). Bu eğretileme, aynı zamanda anlatının temel izleklerinden evrensel görecelik kuramına (Nahon, 1972, s. 19) göndermede bulunmaktadır. "Çünkü bu bütün büyük insanlara yaraşır bir addır" (s. 41). Her şeyin ölçüsü insandır ilkesiyle hareket eden, bütün bilgi ve değerlerin göreli olduğunu ileri süren kuram (Güçlü ve ark. 2003, s. 608), Voltaire'in anlatı boyunca sürekli yararlandığı bir kaynaktır. Ünlü düşünürün kesinlik üzerine şu ifadesi görecelik kavramına atıfta bulunmaktadır:

Copernicte'ten önce bütün dünyaya "Bu güneş doğdu mu battı mı?" diye sorsaydınız herkes şu cevabı verirdi: "Bundan kesin olarak eminiz." Kesin olarak emindiler ama yaniliyorlardi.

Büyüler, bilicilikler, saplanılan fikirler, uzun zaman bütün ulusların gözünde dünyanın en keskin şeylerindendi. Sayısız insan kalabalıkları bu güzel şeyleri ne görmüşler ne de kesin olarak emin olmuşlardı! (Voltaire, 1977a, s. 168).

Anlatıdaki küçük-büyük eğretilemesi ile yazar olguların önyargılarla değerlendirilemeyeceğini, gerçekliğin zamana ve mekâna göre değişebileceğini iddia etmektedir. "Dört yüz elli yaşına doğru, çocukluktan çıkarken" (s. 43) ve "bu ülkenin vatandaşları $2000 \mathrm{~m}$ civarında cücelerdi" (s. 44) sözceleri, Micromégas'nın kendi gezegeninde doğal karşılanan fiziğinin bir başka dünyada ne denli sıra dışı olduğunu gösterir. Önyargıları duygusal, fiziksel, tarihsel ve dinsel olmak üzere dört başl1kta inceleyen Voltaire'e göre önyarg1, akıl yürütmeden kabul edilmiş bir inançtır (Voltaire, 1977b, s. 290-295). Micromégas ve Sekreter arasındaki şu diyalog ise fiziksel önyargıların ne denli sorgulanabilir olduğunu izah etmektedir:

Siriuslu (Micromégas), "Ne kadar yaşarsınız?" diye sordu. Satürnlü küçük adam (sekreter), "Ah, çok az" dedi. Siriuslu, "Tıpkı bizim gibi" dedi. "Her zaman yaşamın kısalığından yakınıyoruz. $\mathrm{Bu}$, evrensel bir doğa yasası olmalı". "Ne yazık ki” dedi Satürnlü. "Ancak, Güneş beş yüz dönüşünü tamamlayıncaya kadar (yaklaşık on beş bin Dünya y1lı) yaşıyoruz”. (...) Micromégas onu şöyle yanıtladı: "Bir filozof olmasaydını, ömrümüzün sizinkinin yedi yüz katı olduğunu söyleyerek sizi üzmekten çekinirdim ..." (s. 47).

Anlaşlacağ1 üzere az-çok, küçük-büyük gibi izafi kavramlar zaman ve mekân bağlamında anlam kazanmaktadır.

Satürn Bilimler Akademisi Sekreteri ise gelenekleri gereği kendi gezegeninin Cizvit kolejinde okumuş ve "zekâsının gücüyle Euclides'in önermelerinden 
ellisini” çözmüş bir fillozoftur (s. 42). Cizvitler Papa III. Paul tarafindan 1540 yılında resmen tanınan bir Hristiyan tarikatıdır. Kurucusu Ignatius'un diğer tarikatlardan örnek aldığı birçok husus olmakla birlikte; kendine has itaat anlayışı, eğitim sistemi ve misyoner karakteri ile diğer tarikatlardan ayrılmaktadır. Başta teoloji olmak üzere tarih, felsefe ve sanat alanındaki çalışmaları tarikata haklı bir şöhret kazandırmıştır. Felsefe alanında en çok değer verdikleri filozof ise Aristoteles'tir. Ignatius, karş1laşttğı zorluklar karşısında, kendi eğitiminden başlayarak, taraftarlarının eğitimiyle devam ederek ve daha sonra bütün insanların eğitimi ve Kilise'ye dönmesini sağlayacak bir eğitim sisteminin temelini atmıştır. Bu eğitim sistemi eğitim tarihçilerince de mükemmel bir eğitim sistemi olarak kabul edilmiştir (Güngör, 2012, s. 66-101). Euclide ise Antik Yunan düşüncesinde Sokratesçi sofist adıyla anılır. Megara okulu kurucusu Euclide, sofistlerin sıklıkla kullandığı haklı çıkma (eristik) sanatını geliştirmiş ve öğretisini göreceliğe yönelen şaşırtıcı kıyaslamalarla güçlendirmiştir (Hançerlioğlu, 1993, s. 77). Anlatıdaki göndergeler anlatı kahramanının düşünce dünyası ve felsefi yaklaşımının okuyucu tarafından daha iyi anlaşılmasını sağlamaktadır.

Anlatıda bir sofist filozofa göndermede bulunulması rastlantısal olmasa gerektir. Hümanizmin egemen olduğu ve insanı merkeze alan M.Ö 5. yüzyıl Yunan felsefesi, sofistlerin felsefi düşünce geleneğinde ağırlıkta oldukları dönemdir. Sofist düşünürler de Cizvit papazları gibi eğitime önem vermekle birlikte, uzlaşımcı, eleştirel, kuşkucu ve gözleme dayalı felsefi yaklaşımları ile kendi dönemlerini etkilemişlerdir. Sofist düşünürlerin, hikâyenin yazarı ile en belirgin ortak noktalarından biri de "görelilik"tir. Mutlak ve değişmez bir hakikat olmayıp bilgi ve hakikat bireyin algılarına, toplumsal, kültürel ve kişisel eğilimlerine göredir düşüncesine sahip sofistler, dış dünyaya ilişkin bilgimizin temelinde duyu organları aracılığıyla gerçekleşen duyu-algılarının bulunduğunu ileri sürmektedirler (Cevizci, 2009, s. 34).

"Eğlence olsun diye Euclide önermelerinin otuz ikisini çözen ve o zamandan beri oldukça sıradan bir geometrici ve çok kötü bir metafizikçi olarak kabul edilen Blaise Pascal (...)" (s. 43) sözcesi ise Cizvit koleji mezunu Micromégas üzerinden, XVIII. yüzyıldaki "Jansenist Anlaşmazlı̆̆a" göndermede bulunmaktadır. Hristiyan geleneğinde heretik bir akım olarak bilinen Jansenistler, insanların ya doğal ya da doğaüstü bir determinizmin kurbanı olduklarını savunur ve Tanrının özel bir lütfu olmaksızın, onun emirlerini yapmanın insan için imkânsız olduğuna inanırlar (Gündüz, 1998, s. 203). Voltaire ise, bu doktrinin felsefi nitelikte ve çözüm sağlayıcı bir içeriğe sahip olmadığını iddia eder. Ünlü düşünüre göre bir gruba mensup olmanın gizli tatminini yaşayan Jansenistler, şöhret arzusu ve akli rahatsızlığın egemen olduğu bir eğitimin eseridirler ve Cizvitlere karşı nefret duymaktadırlar (Güngör, 2012, s. 121).

Satürnlü Akademi Sekreteri kurmaca dünyanın dışında Fransız Bilimler Akademisi Sekreteri Bernard Le Bovier de Fontenelle'i imlemektedir. Fontenelle, Fransiz Akademisi'nin üyesi ve Bilimler Akademisi'nin daimi 
sekreteridir. Düşünce ve bilim alanındaki yenilikleri, halka ulaştırdığı ve halkı bu yönde bilinçlendirdiği için öne çıkmıştır. XVIII. yüzyılın bilimsel öncülerinden biridir. Batıl inançları eleştirdiği Histoire des Oracles (1687) ve kendi çağında yapılan astronomik keşiflerin kurgusal bir diyalogla açıkladığ Les Entretiens sur La Pluralité des Mondes (1686) adlı yapitlarındaki tespitlerle kendini anlatıda hissettirir (Niderst, 1991, s. 279-280). Anlatı kişisi Satürn Akademisi Sekreteri, Micromégas'nın "bin kadar duyusuna" karş1 "yetmiş iki duyuya" (s. 46) sahiptir. Onun "otuz bin kral ayağına" (s. 51) denk gelen bir adımı ise Sekreterin on iki ayağına (s. 52 ) denk düşmektedir. "Büyük okyanusun dizlerini aşmamış" olan (s. 52) Sekreter, Micromégas'nın yanında sadece "Satürnlü bir cücedir" (s. 59). Siriuslu için "bir cüce olan" Sekreter, dünyada ise "bir balinayı tırnağının üzerine" (s. 54) koyabilecek bir devdir.

Anlatı kişileri aynı zamanda birer toplumsal kimliği niteleyen "tip" dirler. Micromégas ve Akademi Sekreteri "iki iyi yürekli gezgin" (s. 66) ve "meraklı" (s. 50 ) "filozofturlar" (s. 49). Filozoflar aynı zamanda "bilgin" (s. 64) olarak nitelendirilmektedirler. $\mathrm{Bu}$ bilgin insanlar yalnızca "benzetmeler yoluyla ak1l yürüten insanlara güvenirler” (s. 50). Voltaire'e göre ise filozof, bilgeliği yani doğruyu seven insandır. Coşkunluk göstermeyen, hiçbir zaman peygamberlik iddiasında bulunmayan ve Tanrıdan esinlendiğini sanmayan bilgedir. Filozof boş fizik sistemleriyle yetinmez; onun yerine insanlara temiz bir ahlak öğretir ve insanın yaradılışındaki kötülüğü düzeltmek ister (Voltaire, 1977b, s. 273281).

Anlatıdaki filozoflar da adeta Voltaire'in bu serimlemesinin vücut bulmuş tipleridir. Anlatı kahramanlarının dünyaya varışlarıyla birlikte diğer filozoflarla felsefi tartışmalara koyuldukları VII. Kesitte, Aristoteles, Descartes, Malebranche, Leibniz ve Locke'un (s. 64) felsefi yaklaşımları tartışmaya açılmaktadır. Böylelikle anlatı kahramanları da kendi felsefi yaklaşımlarını okuyucunun dikkatine sunmaktadırlar. Micromégas,

(...) her zaman sadece duyularımın yardımıyla düşünmüş olduğumu biliyorum. Maddi olmayan varlıkların mevcudiyetinden kuşku duymuyorum,(...). Ebedi güce sayg1 duyuyorum; ona sınır koymak bana düşmez. Hiçbir sav ileri sürmüyorum; düşündüğümüzden çok daha fazla şeyin olası olduğuna inanmakla yetiniyorum (s. 66)

diyen Locke taraftarını diğerlerinden daha bilge bulurken; Aristotelesçi "entelekya", Descartescı "metafizik ve madde", Malebrancheçı "ruh algısı", Leibnizci "ruhun evrenin aynası, bedenin aynanın çerçevesi" olduğunu iddia eden bakış açılarını eleştirmektedir. Akademi sekreterinin ise "Locke'un çömezini kucaklamak istemesi”, Micromégas ile aynı felsefi yaklaşımı paylaştığını göstermektedir. İngiliz deneycilik okulunun kurucusu olan Johne Locke, zihinde "doğuştan düşünceler" bulunmadığını ve bilginin deneyimden üretildiğini iddia etmektedir. Düşünür, insanın bilgiye temel olan malzemeyi sonradan deneyim yoluyla kazandığını söyler. Deneyim, dış deneyim ve iç deneyim olarak iki başlıkta ele alınır. Dış deneyimde insan beş duyu yolu ile diş dünyadaki şeyleri tecrübe ederken; iç deneyimde ise insan varlı̆̆ı, kendi 
zihninde, kendi iç dünyasında olup bitenleri tecrübe eder. İnsan zihnindeki tüm ideler, işte bu iki kaynağın birinden ya da diğerinden gelir (Cevizci, 2009, s. 1021-1022). Hikâyenin yazarı Voltaire'in İngiliz düşünüre göndermede bulunması nedensiz değildir. İngiltere'deki sürgün yıllarının sonunda sürgün ülkesindeki izlenimlerini bir araya toplayan yapita Felsefi Mektuplar (Lettres Philosophiques) (1734) adını vermesi ve ikiyüzlü düşünürlerden bahsederken; "Neden böylelerine İngiltere'de hiç rastlanmaz da Fransa'da hala rastlanır? Filozoflar bu sorunu çözmek sizler için güç olmayacaktır" (Voltaire, 1977b, s. 281) ifadesini kullanması Voltaire'in bu yaklaşımını açıklamaktadır.

Her iki anlatı kahramanının önceki paragrafta vurgulanan felsefi yaklaşımı benimsiyor olmaları, her konuda hemfikir olduklarını göstermemektedir. Akademi Sekreteri muhatabının hoşuna gitmesi için betimlemelerinde benzetmelere başvururken; Micromégas "hoşuma gidilmesini değil, bana bir şeyler öğretilmesini istiyorum" (s. 46) demektedir. Akademi Sekreteri'nin, "hiç kimsenin burada oturmak istemeyeceğini düşündügüm için, burada kimsenin olmadığı sonucuna vardım" (s.53) yanılgısına düşmesinin nedeni ise "çok çabuk yargıya varıyor" (s. 52) ve "görünüşe aldanıyor" (s. 56) olmasıdır. Buna karşı1lık Micromégas ise yargıya erken varmanın aldatıcı olabileceğini, sezilerin yol gösterici olabileceğini, akıl yürütmenin ve gerçeğe ulaşmak için kimi araçları kullanmanın insanı yanlış çıkarımlardan kurtarabileceğini savunmaktadır (s. 57). Siriuslunun, "artık ne inanmaya ne de inkâra cesaretim var; neye inanacağımı bilemiyorum. (...) daha sonra akı1 yürütürüz (s. 58) sözcesi”" Micromégas'nın haklılığını teyit etmektedir.

Gerçekliğin göreceliği ve düşüncenin farklı yönleri, anlatı boyunca filozoflar üzerinden serimlenir. XVIII. yüzyı1 Fransa's1 filozoflar yüzyılı olarak bilinmektedir. Yunanca sevmek anlamına gelen "phileo" ve bilgi, bilgelik anlamına gelen "sophia" sözcüklerinden oluşan ve bilgi severlik karş1lı̆g 1 verilebilecek (philosophia) felsefe, yüzyıla damgasını vurmuştur. Özgür düşünce kendini felsefe ile beslerken skolastik düşüncenin gölgesi henüz daha çağın üzerindedir. Avrupa'da XIII. yüzyıl sonuna kadar, önceleri kilise okullarında, daha sonraları da üniversitelerde yaygın biçimde benimsenen düşünce öğretisi (Güçlü ve ark.2003, s. 1313) olan skolastik düşünce, dinî bir bağnazlık olmasa da bilim adına yürütülen bir başka bağnazlığa yerini bırakmıştır.

Micromégas'nın kitabında "kuşkulu, yakışıksız, cüretkâr, aykırı düşünceler ve dinin temel ilkelerine ters düşen noktalar" tespit edilerek açılan "dava pirelerin yapısının esas olarak salyangozlarınkiyle aynı olup olmadığını" konu edinen bir dava halini alırken; "ülkesinin, olur olmaz şeyler için hır çıkarmaktan hoşlanan cahil mi cahil" müftüsünün açtığı bu soruşturma, "onun kitabını, kitabın kapağını açmamış hukukçularca" mahkûm edilir (s. 42). Anlatı boyunca dini karakterli anlatı kişileri sürekli olarak felsefi düşüncenin karşısında konumlandırılmışlardır. "(...) Göklerin bu en yüksek katına serpilmiş yıldızlar arasında papaz Derham'ın dürbünüyle görmüş olmakla övündüğü şeyi asla görmedi (s. 44); Peder Castel'in oldukça eğlenceli yazılarla bu iki Ay'ın 
varlığına karşı çıkacağını biliyorum" (s. 50) sözceleri ile dinî bağnazlığa göndermede bulunurken Lockecu bilgi edinim kuramına da göndermede bulunulmaktadır. Voltaire için bağnazlık (fanatisme), Roma dönemindeki ilk anlamı itibarıyla "bir tapınağa hayır işleyen kimse" demektir. Kavram bugün ise karanlık, zalim bir din çılgınlığı anlaşılmaktadır. Bir erdem okulu olarak anılan Kilise tarihi aynı zamanda bütün tarikatlar tarafından ötekilere karşı kullanılmış bir fesat okuludur ve bağnazlık insanların gözünü kör eder (Voltaire, 1977b, s. 415-418). Ünlü düşünürün bağnazlığa atfen sarf ettiği son cümle, hikâyenin ilk kesitinde sözünü ettiği Cizvit ve Jansenist çatışmasına göndermede bulunmaktadır. Anlatı kişilerinden "Peder Castel", Newton düşüncesine karşı çıkan Traité de la Pesanteur Universelle (1724) yapıtının yazarı ve Cizvit tarikatına mensup olan Louis Bernard Castel'e göndermede bulunmaktadır. "Papaz Derham" ise tabiatının olağan üstünlüklerinden hareketle Tanrının varlığını ispatlamaya çalışan, Physico-theology, or a Demonstration of the Being and Attributes of God (1723) adlı yapıtın yazarı İngiliz düşünür William Derham'a göndermede bulunmaktadır.

Neye uğradığını kavrayamayan geminin papazının "iki belayı def etmek için dualar okumaya başlaması" (s. 58) ise din adamının Tanrı'nın inayetini dilemesidir. Voltaire ise, inayetten bahsederken ne Homeros'un etkili ve nedensiz inayetini ne de onun gibi düşünmeyen filozofların Tanrı inayetinin her şeyi evrensel yasalarla yönettiği iddiasını doğru bulmaz. Uygun inayetin ise ne olduğunu bilmediğini itiraf eder (Voltaire, 1977b, s. 444-446).

Anlatının VII. kesitinde birbirinden farklı felsefi düşüncelerin ortak kavramlar üzerine yaklaşımları sunulmaktadır. "Bütün filozof hayvancıkların (insanların) sözünü kesen akademik kara şapkalı küçük bir hayvancık vardı; bu hayvancık bütün sırların yanıtının Aquinolu Aziz Tommaso'nun La Somme adlı yapıtında bulunduğunu söyledi" (s. 66) sözcesi Lockecu bilgi teorisini ve skolastik bilgi teorisini karşı karşıya getirmektedir. Yine aynı sözce, önceki paragrafta izah edilmeye çalışılan bağnazlı̆̆ın örneklendirilmesi için önemlidir. Skolastiğin büyük düşünürü Aquino'lu Thomas felsefi düşüncede Aristoteles'i öncelemektedir. Dogmatik olan skolastiğe göre belli bir konuyu okumak, o konuda Aristoteles'in ne yazdığını okumak anlamına gelmektedir. Daha derin bir inceleme, Aquinolu Thomas'nın, Aristoteles'in bu yazısı üstüne ne yazdığını okumak demektir. Bilimsel bir incelemeyse Aristoteles'in ve Aquiono'lu Thomas'nın bu yazılarını tekrarlayan üçüncü bir kitabı okumak demektir. Hiçbir kişisel görüş, tartışma, kuşku ve kurcalamaya izin yoktur (Cevizci, 2009, s. 284). Anlatının bu kesitinde Aquinolu Thomas'a göndermede bulunulması da tesadüfî değildir. Zira felsefede Aristotelesçi yaklaşımı benimseyen Cizvit kolejinden mezun Micromégas'nın karşısına yine Aristotelesçi Aquionolu Thomas'ın çıarılması; skolâstik düşüncenin farklı kimliklerde buluşturulması anlamına gelmektedir. Skolâstik felsefenin değer dizgesi dogmatizm, Voltaire'in de ilgisini çekmiştir. Ünlü düşünür, dogmalar üzerine düşüncelerini ironik bir dille ele alır: 
(...) Bütün bu davalar görüldükten sonra, şu buyruğun ilan edildiğini duydum: "İlksiz yaratıcı, koruyucu, ödül verici, öç alıcı, bağışlayıcı vb. adına bir isteğimizle yaratıverdiğimiz yüz milyon milyar dünyada yaşayan halk bilsin ki, adı geçen halktan hiçbirini boş düşüncelerine değil, yalnızca davranışlarına bakarak yargılayacağız; çünkü adaletimiz böyle emrediyor."

Ne yalan söyleyeyim, böyle bir buyruğu ilk kez dinlemiştim: üzerinde doğduğum o küçük kum tanesinde şimdiye kadar okuduklarımın hepsi şu sözcüklerle bitiyordu: "Çünkü keyfimiz öyle istiyor" (Voltaire, 1977a, s. 299-300).

Micromégas'nın bilgelik nedir sorusuna karşılık aldığı cevap da önemlidir: “(...) çizgileri ölçer, sayıları bir araya getiririz; anladığımız iki-üç konuda anlaşır, anlamadığımız iki üç bin konuda didişir dururuz" (s. 63). Gerçek bilgelik, bilinenden çok bilinmeyenin farkında olabilmektir. Bu örneklemede bilgelik kavramıyla birlikte matematik terimlerinin kullanılması tesadüfî değildir. Micromégas ve Akademi Sekreteri, Satürn atmosferine açılırken "hatırı sayılır miktarda matematik aletiyle" (s. 49) yola çıkarlar. Bu iki devasa yaratıkla karşılaşan bir fizikçinin, sekreterin boyunu "bin toise" (s. 60) olarak tahmin etmesi ve insanların "üçgenlere bölme yöntemiyle" (s. 60) devin yaşını tahmin etmesi matematik, geometri ve fiziğin bilgelik için önemine göndermede bulunmaktadır. Voltaire' in şu ifadesi, ilgili göndergeleri açımlamaktadır:

(...) Aynı zamanda hem var olmama, hem var olmamama, hem duymama, hem de duymamama olanak yoktur. Bir üçgenin aynı zamanda, iki düz açının toplamı olan hem yüz seksen derecesi olmasına, hem de olmamasına olanak yoktur.

Varlığımın, duyarlılığımın fizik kesinliğiyle matematik kesinlik, başka türden olmakla beraber, demek ki aynı değerlerdir. (Voltaire, 1977a, s. 169).

Anlatının sonunda ise, Micromégas'nın insanlara olguların niteliğini anlatmak üzere kaleme aldığını söylediği yapıtını hediye etmesiyle, anlatı son mesajını da okuyucuya sunmaktadır: "Bilginler, kitabı Paris'e Bilimler Akademisi'ne götürdüler; ama Akademi Sekreteri kitabı açtığında sayfaların bomboş olduğunu görerek, "Ben de bundan kuşkulanıyordum" dedi".

Anlatı kahramanlarının çevresinde meydana gelen olay zinciri, gerek göndergeler gerekse de betimlemeler aracılı̆̆ıla okuyucuya bir öğreti sunma amacını gütmektedir. Aktarılan konuşma sahneleri ise anlatı kişilerinin felsefi yaklaşımlarının sunulduğu ve açımlandığı sahnelerdir. Anlatı kahramanları için yapılan tanımlamalar, olgular karşısında takındıkları tavrın nedeni olarak kapalı bir göndermeye dönüşürler. Adeta bir düşünce firtınasını andıran olay zinciri, anlatıcının gözlemlediği ve anlatının başkahramanlarından Micromégas'nın yönlendirdiği felsefi bir seyirdir. Anlatının ilk kesitinden itibaren Micromégas'nın imlediği görecelik kuramı, anlatı sonunda ironik bir dille özetlenir. Olguların niteliğine dair yazıldığı söylenen yapıtın, dönemin bilimsel otoritesi sayılan Bilimler Akademisi Sekreteri'ne sunulması ve sunulan yapitın sayfalarının boş olması; "görelilik kuramına" dair yapılan tespitlerin ve göndermelerin, anlatının sonunda doğrulanması olarak görülebilir. Böylelikle Voltaire, anlatıcının refakatinde sürdürdüğ̈ parodik sorgulamaları hikâyenin sonunda ironik bir biçemle sonlandırmıştır. 


\section{Sonuç}

Yazın tarihine dair akademik kaynaklardan yapılan artsüremli okuma, XVIII. yüzyıl Fransız düşünürü Voltaire'in imgesel bir yolculuk izleği üzerine kurguladığı Micromégas adlı felsefi hikâyesini yine XVIII. yüzyıl İngiliz yazarı Jonathan Swift'ten etkilenerek kaleme aldığını işaret etmektedir. Daha sonra, yazarın İngiltere'deki sürgün yıllarında tanıştı̆̆ 1 Swift'in, imgesel bir yolculuk izleğini merkeze alan Gulliver'in Seyahatleri adlı eserinin de M.Ö II. yüzyılda yaşamış olan Lukianos' tan esinlenerek kaleme aldığı iddiasının izi sürülmüștür. İncelenen akademik kaynaklar 1şığında, her üç yapıtın biçemsel ortaklıkları tespit edilmeye çalışılmıştır. Kendi ülkesinde anlaşılamayan; suçlamalara ve sürgünlere maruz kalan Voltaire'in yaşam öyküsü Anglo-İrlandalı Swift'le benzer hayal kırıklıklarına ve ötekileştirmelere sahne olur. Swift'in esin kaynağ 1 olan, Batı felsefesi ile yoğrulmuş Doğulu filozof Lukianos da anılan yazarlarla benzer hayal kırıklıklarına ve başarısızlıklara uğramıştır. Yazgıları ve tercihleri sonucunda yaşadıkları tecrübeler, ele alınan eserlerin yazarlarının da farklı coğrafyalarda ve farklı yüzyıllarda yaşama karşı benzer bir tavır sergilemelerine neden olmuştur. Bilim-felsefe çatışması merkezinde değerlendirilen Micromégas, Voltaire'in XVII. yüzyıl itibariyle seyreden bilimsel gelişmelere koşut Fransız Aydınlanma Felsefesinin tutumunu yansıtmaktadır. Adeta Ortaçağ Avrupa düşüncesinin Tanrı merkezli bakış açısının izlerini silmeye çalışan Voltaire, profan kült ile Hristiyan teolojisinin sentezi, Hristiyan felsefesinin yerini alan usçu yaklaşımın öncekini aratmayacak ölçüde tabulaşmasına karşı tavır alır. Voltaire yapıtında, Helenistik felsefe çağından beri farklı okullar ve düşünürlerce ele alınan ve düşünsel evrimini sürdüre gelen "görelilik" kuramına göndermelerde bulunmaktadır. Anılan dönemlerde öne çıkmış düşünürlere ve yaklaşımlarına göndermelerde bulunulan diyaloglarda faklı görüşler ve tartı̧̧malar okuyucunun dikkatine sunulmaktadır. Felsefi hikâyenin kendine özgü biçemi gereği bu felsefi tartışmalarda, anlatıcı tarafsız kalmakla birlikte okuyucuyu da bu tartışmaların içine sürüklemeye ve akıl yürütmeye yönlendirmektedir.

\section{KAYNAKÇA}

Barut, E. (1999).Gulliver's Travels: Horses and Men. Balıkesir Üniversitesi Sosyal Bilimler Enstitüsü Dergisi, 2 (3).

Bourque, G. (1976). La Parabole. Etudes Littéraires, 9 (1).

Charpenter, M. et Charpenter, J. (1987).Littérature Textes et Documents- XVIII Siècle. Paris: Edition Nathan.

Cevizci, A. (2009).Felsefe Tarihi. İstanbul: Say Yayınları.

William A. E. (Nov. 1921). A Source for Gulliver's Travels. Modern Languages Notes, 36 (7).

Eliot, C. W. (1909). Stories from the thousand and one nights: The Arabian night's entertainments: The Harvard Classics: Dr Eliot's five-foot shelf of 
books. (Tr. Edward William Lane, F. Collier \& Son). New York: Harvard University Press.

Georgiadou, A. and Larmour, David H. J. (1988). Lucian's Science-Fiction Novel True Histories. Netherlands: Brill Edition.

Güçlü, A., Uzun, E., Uzun, S., Yolsal, Ü. H. (2003). Felsefe Sözlüğü. Ankara: Bilim ve Sanat Yayınları.

Gündüz, Ş. (1998). Din ve İnanç Sözlüğ̈̈. Ankara: Vadi Yayınları.

Güngör, A. İ. (2012). Cizvitler. Ankara: Berikan Yayınevi.

Hançerlioğlu, O. (1993). Düşünce Tarihi. İstanbul: Remzi Kitabevi.

Havens, G. R. (1971). Voltaire Tarihçi. Fikirler Çă̆ı. (Çev. Dr. Behzad K. Yeğen). İstanbul: Milli Eğitim Basımevi.

Lersen, W. (2005). Jonathan Swift and Ireland. Oslo: The Department of Literature, Area Studies and European Languages, The University of Oslo.

Lukianos, S. (1944a). Seçme Yazılar I. (Çev. Nurullah Ataç). Ankara: Maarif Matbaasi.

(1944b). Seçme Yazılar II. (Çev. Nurullah Ataç). Ankara: Maarif Matbaas1.

(1944c). Seçme Yazılar III. (Çev. Nurullah Ataç). Ankara: Maarif Matbaas1.

Marsh, D. (1998). Lucian and The Latins. Michigan: University of Michigan Press.

Maurois, A. (2001). Voltaire. (Çev. Cenap Yazansoy). İstanbul: Kastaş Yayınlar1.

Nahon, H. (1972). Schématisation des personnages dans les contes philosophiques de Voltaire. Montreal: Faculty of Graduate Studies and Research, Mcgill University.

Niderst, M. A. (1991). La Diffusion des Sciences au XVIIIe siècle. Revue d'Histoire des Sciences, 44.

PARRAU, A. (2013). Le Conte Philosophique. Histoire Littéraire, TDC, 1045.

PAUL, R. (1925). Sybil Goalding. Swift en France. Revue Belge de Philologie et d'Histoire, 4 (2).

Rychlewska-Delimat, A. (2011). Le Conte Philosophique Voltairien Comme Apologue. Synergies Pologne, (8).

Shank, J. B. (Summer 2010). Voltaire. The Stanford Encyclopedia of Philosophy. Edward N. Zalta (Ed.).

Swift, J. (1958).Gulliver'in Seyahatleri. (Çev. Prof. İrfan Şahinbaş). Ankara: Maarif Basimevi.

(1961).Gulliver's Travels. An Annotated Text With Critical Essays.

Robert A. Greenberg (Ed.). New York: Norton. 
Tanilli, S. (2007). Voltaire ve Aydınlanma. İstanbul: Alkım Yayınları. (2007). Candide ya da Iyimserlik. İstanbul: Alkım Yayınları.

Voltaire. (1960). Romans et Contes. (Ed. Henri Benac). Paris: Edition Garnier Frères.

(1977a). Felsefe Sözlüğ̈̈ 1. (Çev. Lütfi Ay). Ankara: İnkılap ve Aka Yayınevleri.

(1977b). Felsefe Sözlüğü 2. (Çev. Lütfi Ay). Ankara: İnkılap ve Aka Yayınevleri.

(2002). Micromégas. (Çev. Hasan Fehmi Nemli).Ankara: Dost Kitabevi Yayınları.

(2006).Candide and Other Stories. (Tr. Roger Pearson). New York: Oxford University Press.

Wade, I. O. (1950). Voltaire's Micromégas. New Jersey: Princeton University Press.

Whibley, C. (1902). Introduction. Lucian's True History. (Tr. Francis Hickes). London: A. H. Bulley.

Zekiyan, B. (1982). Insancılık. İstanbul: İnk1lâp ve Aka Kitabevleri.

\section{ON VOLTAIRE AND HIS PHILOSOPHICAL STORY MICROMEGAS}

Abstract: The 18th century celebrated French philosopher and writer Voltaire transferred his sentiments and ideas that he experienced during his life to the literary domain. The philosopher as a writer of poetry and tragedy was affected by the people that he met and by the events that he experienced. His criticism towards to the age and the society that he lived in influenced the thinkers of his age and the descendents by his original approach philosophy and style. Voltaire's philosophical story Micromégas reveals the conflict of science and philosophy in the 18th century. The evaluation of the scientific specifications as the only reality and invariable principles by the age's scientists, was criticized by the philosopher within the scope of the theory of relativity. Voltaire expresses that the forthcoming centuries can evaluate the truth of the age as an illusion by putting philosophical interrogations towards to the scientifically truth. Both the form of the story and the philosophical approaches to the fictional character are important for the philosopher in order to specify the method of the discussion and the proponents. Despite the author being named as the creator of the philosophical story, by means of a diachronic research, we see that the fact is different. The philosophers and literary works that Voltaire met during the exile years when he took refuge in England effected the author's imagination. Jonathan Swift is predominant between these authors. According to the certain evaluations in various academically resources, the celebrated English author wrote his story which tells about an imaginary travel, as inspired by the True Story of Lucian who lived in $2^{\text {nd }}$ century B.C II. The 
common thematic and stylistic features of the three works and the conflict of science-philosophy are discussed in the present study.

Keywords: Pilosophical Story, Voltaire, Jonathan Swift, Lucian, Travel. 